\title{
H2AX phosphorylation screen of cells from radiosensitive cancer patients reveals a novel DNA double-strand break repair cellular phenotype
}

\author{
RS Vasireddy ${ }^{1,2,8}$, CN Sprung ${ }^{1,3,4,8}$, NL Cempaka ${ }^{1,2}$, M Chao $^{1,5}$ and MJ McKay, ${ }^{*, 1,2,6,7}$ \\ 'Division of Research, Peter MacCallum Cancer Centre, St Andrews Pl., Melbourne, Victoria 3002, Australia; '²Department of Pathology, University of \\ Melbourne, Melbourne, Victoria 30 I0, Australia; ${ }^{3}$ Department of Biochemistry and Molecular Biology, University of Melbourne, Melbourne, Victoria 3010 , \\ Australia; ${ }^{4}$ Centre for Women's Health Research, Monash Institute for Medical Research, Monash University, 246 Clayton Road, Clayton, Victoria 3168 , \\ Australia; ${ }^{5}$ Radiation Oncology Victoria, East Melbourne, Victoria, Australia; ${ }^{6}$ Department of Radiation Oncology, The Canberra Hospital, Building 3 , \\ Level I, Yamba Drive, Garran, ACT 2606, Australia; ${ }^{7}$ The Australian National University, Canberra, ACT 2600, Australia
}

BACKGROUND: About I-5\% of cancer patients suffer from significant normal tissue reactions as a result of radiotherapy (RT). It is not possible at this time to predict how most patients' normal tissues will respond to RT. DNA repair dysfunction is implicated in sensitivity to RT particularly in genes that mediate the repair of DNA double-strand breaks (DSBs). Phosphorylation of histone H2AX (phosphorylated molecules are known as $\gamma \mathrm{H} 2 \mathrm{AX}$ ) occurs rapidly in response to DNA DSBs, and, among its other roles, contributes to repair protein recruitment to these damaged sites. Mammalian cell lines have also been crucial in facilitating the successful cloning of many DNA DSB repair genes; yet, very few mutant cell lines exist for non-syndromic clinical radiosensitivity (RS).

METHODS: Here, we survey DNA DSB induction and repair in whole cells from RS patients, as revealed by $\gamma H 2 A X$ foci assays, as potential predictive markers of clinical radiation response.

RESULTS: With one exception, both DNA focus induction and repair in cell lines from RS patients were comparable with controls. Using $\gamma \mathrm{H} 2 \mathrm{AX}$ foci assays, we identified a RS cancer patient cell line with a novel ionising radiation-induced DNA DSB repair defect; these data were confirmed by an independent DNA DSB repair assay.

CONCLUSION: $\gamma \mathrm{H} 2 \mathrm{AX}$ focus measurement has limited scope as a pre-RT predictive assay in lymphoblast cell lines from RT patients; however, the assay can successfully identify novel DNA DSB repair-defective patient cell lines, thus potentially facilitating the discovery of novel constitutional contributions to clinical RS.

British Journal of Cancer (2010) I 02, I5 II - 15 I8. doi: I0.1038/sj.bjc.6605666 www.bjcancer.com

(c) 2010 Cancer Research UK

Keywords: $\gamma \mathrm{H} 2 \mathrm{AX}$, radiosensitivity, ionising radiation

Radiotherapy (RT) is one of the main strategies for cancer treatment, and is a prime contributor to cancer patient survival and loco-regional tumour control (Morgan et al, 2004). Radiotherapy dose intensities are typically selected to avoid an unacceptable frequency of severe adverse normal tissue reactions and hence, most patients could potentially tolerate RT dose escalation. This is expected to significantly improve loco-regional cancer control and patient survival. Identification of predictive markers of radiosensitivity (RS) may enable individualisation of $\mathrm{RT}$, which till date has not been achieved in clinical practice.

Many assays with the goal of predicting RS in normal tissues before RT have been attempted, with modest success. Assays that have shown promise include colony survival assays (Brock et al, 1995; West et al, 1998), chromosomal aberration frequency (Neubauer et al, 1997, 2002; Distel et al, 2006), comet assay

\footnotetext{
*Correspondence: Dr MJ McKay; E-mail: michael.mckay@act.gov.au

${ }^{8}$ These authors contributed equally to this work

Received 25 September 2009; revised 19 March 2010; accepted 25

March 2010
}

(Brammer et al, 2001), DNA damage and repair based on pulsedfield gel electrophoresis (PFGE) (Wurm et al, 1994; McKay and Kefford, 1995; Zhou et al, 1998), micronucleus assay (Nachtrab et al, 1998; Sprung et al, 2005), telomere length (McIlrath et al, 2001; Sprung et al, 2008), SNP analysis (Severin et al, 2001; Gurska et al, 2007; Wilding et al, 2007; Alsner et al, 2008), DNA end binding complexes (Ismail et al, 2004) and transcriptional profiling (Rieger et al, 2004; Svensson et al, 2006; Sprung et al, in preparation). Thus, many potential endpoints exist, most of which have been partially successful in identifying clinical RS. Given the probable diversity in molecular pathogenesis of RS and the results from these cellular biophysical and molecular assays, most assays will probably be useful only for a minority of patients. A combination of selected assays may ultimately be successful.

Cancer patients are exposed to ionising radiation (IR) during RT treatment, which causes several types of cellular damage, of which DNA double-strand break (DSB) damage is the most significant, as DSBs can result in clastogenesis, mutagenesis and cell death by diverse mechanisms, including mitotic catastrophe, deletions and/or mutations (Sprung et al, 2002). An early event in DNA DSB 
repair is the phosphorylation of histone $\mathrm{H} 2 \mathrm{AX}(\gamma \mathrm{H} 2 \mathrm{AX})$ at the DSB site, which in less than an hour encompasses a region spanning several megabases (Rogakou et al, 1998), forming a lightmicroscopically visible focus (Rogakou et al, 1999). H2AX protein is phosphorylated on the carboxy terminal at serine 139 by DNAPKcs, ATM or ATR (Rogakou et al, 1998; Paull et al, 2000; Burma and Chen, 2004). The number of DSBs can be directly determined by the number of foci present in the cell shortly after DNA damage (Sedelnikova et al, 2002). Cells either deficient in or with mutations in the large signalling protein kinases that phosphorylate $\mathrm{H} 2 \mathrm{AX}$ are typified by radiation sensitivity, DNA repair defects and genomic instability (Shiloh, 2001). Phosphorylation of $\mathrm{H} 2 \mathrm{AX}$ at the site of a DSB induces chromatin remodelling, further amplifying the signal response cascade and resulting in downstream events such as cell cycle arrest, checkpoint activation and cell death (Shiloh, 2003; McGowan and Russell, 2004). $\gamma$ H2AX has been found to recruit various repair factors to the site of DNA damage, has an anchoring function and also retains the broken chromosomal ends in close proximity (Bassing and Alt, 2004). Although initial migration of various signalling and repair factors to DSBs occurs very rapidly (Nelms et al, 1998), accumulation into visible IR-induced H2AX foci becomes apparent long after DNA damage, with co-localisation of 53bp1, Mdc1, Mre11, Rad50, Nbs1, Rad17 and Brcal to foci developing afterwards (Paull et al, 2000; Stucki and Jackson, 2006; Spycher et al, 2008). $\gamma \mathrm{H} 2 \mathrm{AX}$-deficient cell lines can maintain DSB-induced signalling, and $\gamma \mathrm{H} 2 \mathrm{AX}$ formation is not necessary for non-homologous end joining and homologous recombination-mediated DNA DSB repair, but these processes have decreased efficiency in such cells (Petersen et al, 2001; Bassing et al, 2002; Celeste et al, 2003).

The half-life of $\gamma \mathrm{H} 2 \mathrm{AX}$ foci after DNA damage is approximately $2-7 \mathrm{~h}$ in various cell types (MacPhail et al, 2003; Bouquet et al, 2006). Focus loss may be because of non-repair events that contribute to assay background. Although selection of appropriate controls can potentially overcome this issue, they may have an impact on assay sensitivity. Bouquet et al formally documented, as would be logical to expect, that loss of $\gamma \mathrm{H} 2 \mathrm{AX}$ foci can be because of dephosphorylation. Recent genetic and biochemical approaches have shown the role of phosphatases in the removal of the $\gamma \mathrm{H} 2 \mathrm{AX}$ phosphate group at DSB sites (Chowdhury et al, 2005; Keogh et al, 2006). Another possibility is $\gamma \mathrm{H} 2 \mathrm{AX}$ exchange, which involves replacement of phosphorylated $\mathrm{H} 2 \mathrm{AX}$ with an unphosphorylated $\mathrm{H} 2 \mathrm{AX}$, for which there is evidence in yeast and Drosophila (Kusch et al, 2004; Svetlova et al, 2007). It has been proposed that the signal for $\gamma \mathrm{H} 2 \mathrm{AX}$ depletion is completion of a critical DNA repair step.

Before this study, $\gamma \mathrm{H} 2 \mathrm{AX}$ was approved as a marker of DNA damage and repair and was considered likely to be an improved candidate predictive assay, as it is associated with DSBs in their native and post-irradiation modulated chromatin and is a main lesion following radiation, with foci being easily visualised and quantitated. In addition $\gamma \mathrm{H} 2 \mathrm{AX}$ foci are assayed in situ and can be observed in a reasonable time frame following IR treatment, which is an important clinical requirement for a predictive assay. As there is a lag time to full completion of DNA DSB repair, as measured by $\gamma \mathrm{H} 2 \mathrm{AX}$ foci assays, it is believed that the recovery of non-phosphorylated H2AX must be associated with factors other than just the rejoining of broken DNA, such as proper chromatin organisation (Olive and Banath 2004).

$\gamma \mathrm{H} 2 \mathrm{AX}$ foci kinetics have been examined in a number of RS cellular models. Tumour cell lines of lower RS showed slower rates of $\gamma \mathrm{H} 2 \mathrm{AX}$ depletion than more RS cell lines (Banath et al, 2004; Olive and Banath, 2004; Taneja et al, 2004). Likewise, H2AX phosphorylation depletion was found to be slower in cells with higher intrinsic RS (Olive and Banath, 2004). Increased cellular RS in 18 tumour cell lines, as measured by clonogenic survival, correlated with increased residual $\gamma \mathrm{H} 2 \mathrm{AX}$ foci (Klokov et al, 2006) and other previous DSB repair methods. However, not all studies have found correlations between $\gamma \mathrm{H} 2 \mathrm{AX}$ foci and RS. For example, no such correlation was observed in primary fibroblasts from acute RS $v s$ control patients (Mahrhofer et al, 2006). Moreover, no correlation of $\gamma \mathrm{H} 2 \mathrm{AX}$ foci kinetics was observed in peripheral blood mononuclear cells from prostate cancer patients with late effects (Olive et al, 2008).

Quantification of $\gamma \mathrm{H} 2 \mathrm{AX}$ foci using immunocytochemistry (ICC) is the most sensitive method, with a detection potential of a single focus within the nucleus (Qvarnström et al, 2004). Here we use $\gamma \mathrm{H} 2 \mathrm{AX}$ ICC methods and our collection of lymphoblast cell lines (LCLs) derived from severe RS patients (both acute- and lateeffect cases), using molecular-based assays focusing on DNA breakage and repair in an attempt to identify individuals who show abnormal phenotypes.

\section{MATERIALS AND METHODS}

\section{Cell culture}

Cancer patient lymphocyte cells were isolated from individuals who did and did not have a severe reaction to RT, and LCLs were derived as previously described (Neitzel, 1986; Severin et al, 2001; Sprung et al, 2005). Radiosensitive LCLs were derived from patients who had been classified as Radiotherapy Oncology Group (RTOG) 3 or 4; LCLs classified as RTOG $0-1$ were selected for use as controls. The ataxia telangiectasia (AT)-deficient LCLs were derived in the same manner. The ligase IV human knock-out LCLs were derived from a Nalm6 cell line as described previously (Distel et al, 2003; Sprung et al, 2008). The clinicopathological patient characteristics are presented in Table 1. Lymphoblast cell lines were grown in RPMI-1640, $10 \%$ FBS and $20 \mu \mathrm{g} \mathrm{ml}^{-1}$ of gentamicin in a humidified $5 \% \mathrm{CO}_{2}$ environment.

\section{$\gamma \mathrm{H} 2 \mathrm{AX}$ foci immunofluorescence}

After two washes in phosphate-buffered saline (PBS: $137 \mathrm{mM} \mathrm{NaCl}$, $2.7 \mathrm{~mm} \mathrm{KCl}, 10 \mathrm{~mm} \mathrm{Na}_{2} \mathrm{HPO}_{4}, 2 \mathrm{mM} \mathrm{KH}_{2} \mathrm{PO}_{4}$ ), LCLs were plated at a concentration of $7 \times 10^{5}$ cells per $\mathrm{ml}$ in fresh RPMI. The cell lines were coded, and so the results were obtained without knowledge of the RS status of the patient from whom they were derived. Cells were exposed to $0 \mathrm{~Gy}, 1,2$ or $4 \mathrm{~Gy}$ of gamma radiation from a ${ }^{137} \mathrm{Cs}$ source at a dose rate of $0.62 \mathrm{Gymin}^{-1}$ on ice and then placed at $37^{\circ} \mathrm{C}$ for $1 \mathrm{~h}$. Aliquots of $0.7 \times 10^{5}$ cells were cytospun for $5 \mathrm{~min}$ at 500 r.p.m. onto polysine slides (Menzel-Glaser, Braunschweig, Germany). The slides were fixed for $5 \mathrm{~min}$ with $4 \%$ paraformaldehyde (Sigma-Aldrich, St Louis, MO, USA), rinsed with PBS, and then the cells were permeabilised for $5 \mathrm{~min}$ in $0.1 \%$ Triton X-100 followed by three 5-min PBS washes. Slides were treated thrice for $10 \mathrm{~min}$ in a blocking solution of $1 \%$ bovine serum albumin (BSA) (Invitrogen, Molecular Probes, Eugene, OR, USA). Mouse anti$\gamma \mathrm{H} 2 \mathrm{AX}$ antibody (Upstate, Lake Placid, NY, USA) was added ( $1: 500$ in $1 \%$ BSA) and incubated for $2 \mathrm{~h}$ in a dark roomtemperature-humidified environment. Slides were then exposed to a secondary goat anti-mouse antibody (1:500 in PBS) conjugated with Alexa-488 (Molecular Probes) and incubated for $1 \mathrm{~h}$ in the dark room-temperature-humidified environment. Slides were rinsed thrice in PBS and stained with $0.2 \mathrm{mg} \mathrm{ml}^{-1}$ of $4^{\prime}, 6-$ diamidino-2-phenylindole (DAPI, Sigma). Using an Olympus microscope with an $\times 60$ oil immersion objective (Olympus IX81, Tokyo, Japan), $\gamma \mathrm{H} 2 \mathrm{AX}$ foci images were acquired using a constant exposure time of $500 \mathrm{~ms}$. Eight to ten z-sections with a $0.5-\mu \mathrm{m}$ step size were deconvoluted to obtain $\gamma \mathrm{H} 2 \mathrm{AX}$ foci images for counting using Metamorph (Molecular Probes), by applying morphological filters, Top-hat and H-dome with constant thresholds set at 40 (low) to 1500 (high). Foci count primary data are presented in Supplementary Table S1. Blood collection from patients was approved by the Peter MacCallum Cancer Centre Ethics Committee and informed consent was obtained from all patients. 
Table I Patient characteristics

\begin{tabular}{|c|c|c|c|c|c|c|c|}
\hline & Cancer type & Cancer site & RTOG & Dose received & Radiosensitivity & Sex & Age \\
\hline \multicolumn{8}{|c|}{ Controls } \\
\hline 1 & Adenocarcinoma & Prostate & $0-1$ & $64 / 32 / 5$ & NA & M & 70 \\
\hline 4 & IDC & Breast & $0-1$ & $46 / 23 / 5$ & NA & $\mathrm{F}$ & 70 \\
\hline 5 & Adenocarcinoma & Prostate & $0-1$ & $66 / 33 / 5$ & NA & M & 82 \\
\hline 6 & None & Nil & $0-1$ & NA & NA & M & 39 \\
\hline 9 & IDC & Breast & $0-1$ & $46 / 23 / 5$ & NA & $\mathrm{F}$ & 47 \\
\hline 10 & Adenocarcinoma & Breast & $0-1$ & $46 / 23 / 5$ & NA & $\mathrm{F}$ & 63 \\
\hline 11 & IDC & Breast & $0-1$ & $50 / 25 / 5$ & NA & $\mathrm{F}$ & 52 \\
\hline \multicolumn{8}{|c|}{ Acute reactors } \\
\hline I & IDC & Breast & 3 & $50 / 25 / 5$ & Erythema, oedema & $\mathrm{F}$ & 59 \\
\hline 2 & SCC & Lung & 3 & $36 / 12 / 5$ & Severe dyspnoea & M & 75 \\
\hline \multicolumn{8}{|c|}{ Late reactors } \\
\hline 1 & Adenocarcinoma & Prostate & 3 & $60 / 30 / 5$ & Rectal bleeding & M & 61 \\
\hline 2 & IDC & Breast & 3 & $46 / 23 / 5$ & Fibrosis & $\mathrm{F}$ & 63 \\
\hline 3 & Adenocarcinoma & Prostate & 3 & $64 / 32 / 5$ & Rectal bleeding, haematuria & M & 63 \\
\hline 4 & Adenocarcinoma & Prostate & 3 & $64 / 32 / 5$ & Rectal bleeding & M & 71 \\
\hline 5 & Adenocarcinoma & Prostate & 3 & $66 / 33 / 5$ & Rectal bleeding & M & 73 \\
\hline 6 & Adenocarcinoma & Prostate & 3 & $64 / 32 / 5$ & Haematuria & M & 67 \\
\hline 7 & $M C$ & Breast & 3 & $46 / 23 / 5$ & Fibrosis & $\mathrm{F}$ & 51 \\
\hline 8 & SCC & Cervical & 3 & $45 / 25 / 5$ & Sigmoid and ureter stricture & $\mathrm{F}$ & 40 \\
\hline 9 & LC & Breast & 3 & $50 / 25 / 5$ & Fibrosis, telangiectasia & $\mathrm{F}$ & 73 \\
\hline 10 & Adenocarcinoma & Prostate & 3 & $64 / 32 / 5$ & Rectal bleeding & M & 78 \\
\hline 11 & LC & Lung & 3 & $40 / 20 / 5$ & Pneumonitis, dyspnoea & $\mathrm{F}$ & 69 \\
\hline
\end{tabular}

Abbreviations: $F=$ female; IDC = infiltrating ductal carcinoma; $L C=$ lobular carcinoma; $M=$ male; $M C=$ medullary carcinoma; $N A=$ not applicable; RTOG = Radiotherapy Oncology Group; SCC = squamous cell carcinoma.

\section{PFGE assay}

${ }^{3} \mathrm{H}$-thymidine was added to log-phase LCLs and the cells were allowed to grow for an additional $24 \mathrm{~h}$ at $37^{\circ} \mathrm{C}$. Lymphoblast cell lines were washed twice with PBS solution $(1.4 \mathrm{M} \mathrm{NaCl}, 0.02 \mathrm{M} \mathrm{KCl}$, $0.05 \mathrm{M} \mathrm{Na}_{2} \mathrm{HPO}_{4}$ and $\left.0.02 \mathrm{M} \mathrm{NaH}_{2} \mathrm{PO}_{4}\right)$. Approximately $4 \times 10^{5}$ cells per $\mathrm{ml}$ from each cell line were irradiated at $40 \mathrm{~Gy}$ on ice, and then transferred to a $37^{\circ} \mathrm{C}$ incubator for time points of $0,30,60,120$ and $240 \mathrm{~min}$. At these time points, aliquots of $2 \times 10^{5}$ cells were mixed in $0.8 \%$ low-melting-point (LMP) agarose diluted in PBS, and $50 \mu \mathrm{l}$ plugs were prepared and stored at $4{ }^{\circ} \mathrm{C}$ for $20 \mathrm{~min}$ until lysis. Lysis was carried out using ice-cold lysis buffer (2\% sarkosyl, $1 \mathrm{mg} \mathrm{ml}^{-1}$ proteinase $\mathrm{K}$, Promega, Madison, WI, USA, in $400 \mathrm{~mm} \mathrm{Na}{ }_{2}$ EDTA, $\mathrm{pH} 8$ ) for $1 \mathrm{~h}$ at $4{ }^{\circ} \mathrm{C}$ and then incubated at $50^{\circ} \mathrm{C}$ for $20 \mathrm{~h}$. Plugs were washed thrice for $30 \mathrm{~min}$ in $0.1 \mathrm{M}$ EDTA and equilibrated in running buffer $(45 \mathrm{~mm}$ Tris base, $45 \mathrm{~mm}$ boric acid, $1 \mathrm{~mm}$ $\mathrm{Na}_{2}$ EDTA, pH 8 (TBE)) for 30 min before PFGE. 0.8\% gels were prepared and run in $0.5 \times$ TBE gel running buffer. Plugs were sealed with $0.8 \%$ LMP agarose and placed in a Gene Navigator (Pharmacia Biotech, Uppsala, Sweden) PFGE unit. Electrophoresis was performed at $6.5 \mathrm{~V} \mathrm{~cm}^{-1}$ at $14^{\circ} \mathrm{C}$, with a pulse rate of 5 and $8 \mathrm{~s}$ for $3 \mathrm{~h}$ each. To view the fraction of DNA released into the gel, the gel was stained using SYBR Gold (Invitrogen, Carlsbad, CA, USA) and imaged using a Molecular Imager FX (Bio-Rad, Hercules, CA, USA). The fraction of DNA released from the gels was cut using SYBR gold stain as a template, and solubilised in concentrated $\mathrm{HCl}$, mixed with a liquid scintillation cocktail (Beckman Coulter, Fullerton, CA, USA) and counted using a tri carb TR2100 scintillation counter (Packard, Meriden, CT, USA).

\section{RESULTS}

$\gamma \mathrm{H} 2 \mathrm{AX}$ foci kinetics were examined in a LCL (control-5; Table 1) $1 \mathrm{~h}$ following treatment with graded IR doses up to $4 \mathrm{~Gy}$. We found a clear and roughly linear dose response, consistent with the data reported by others in this cell type (MacPhail et al, 2003, Figure 1). We observed six $\gamma \mathrm{H} 2 \mathrm{AX}$ foci per nucleus on an average for this cell line before IR, which is typical for endogenous foci (Vilenchik and Knudson, 2003). Irradiation with 1, 2 and $4 \mathrm{~Gy}$ (Figure 1B-D, respectively) resulted in an average of 22,41 and 50 foci per nucleus, respectively, $1 \mathrm{~h}$ after IR. A relative decrease in $\gamma \mathrm{H} 2 \mathrm{AX}$ foci number per Gy and an increase in foci overlap was exhibited at $4 \mathrm{~Gy}$. As doses of 1 and $4 \mathrm{~Gy}$ tended to be non-linear because of foci overlap, we used $2 \mathrm{~Gy}$ for our screening assay, which was consistent with previous reports that showed $2 \mathrm{~Gy}$ to be at the upper end of the linear response range for counting $\gamma \mathrm{H} 2 \mathrm{AX}$ foci using ICC methods (MacPhail et al, 2003).

To confirm the reliability of the ICC assay, we tested LCLs with a known cellular RS phenotype, namely, LCLs with a ligase IV homozygous deficiency and also an ATM-deficient cell line. We found that the ligase IV-deficient cell line had a higher number of foci when compared with the controls $(n=11)$ at $1 \mathrm{~h}$ following IR, with over $30 \gamma \mathrm{H} 2 \mathrm{AX}$ foci per nucleus after $8 \mathrm{~h}$, much higher than the number of foci found in controls, indicating a slow repair rate for these cells (Kuhne et al, 2004) (Figure 2). The ATM-deficient cell lines did not have any significant differences in foci induction or depletion as compared with the controls (Figure 2). This is also consistent with previous findings that, although considerably RS, ATM-mutated homozygous cell lines repair bulk DNA DSBs with 

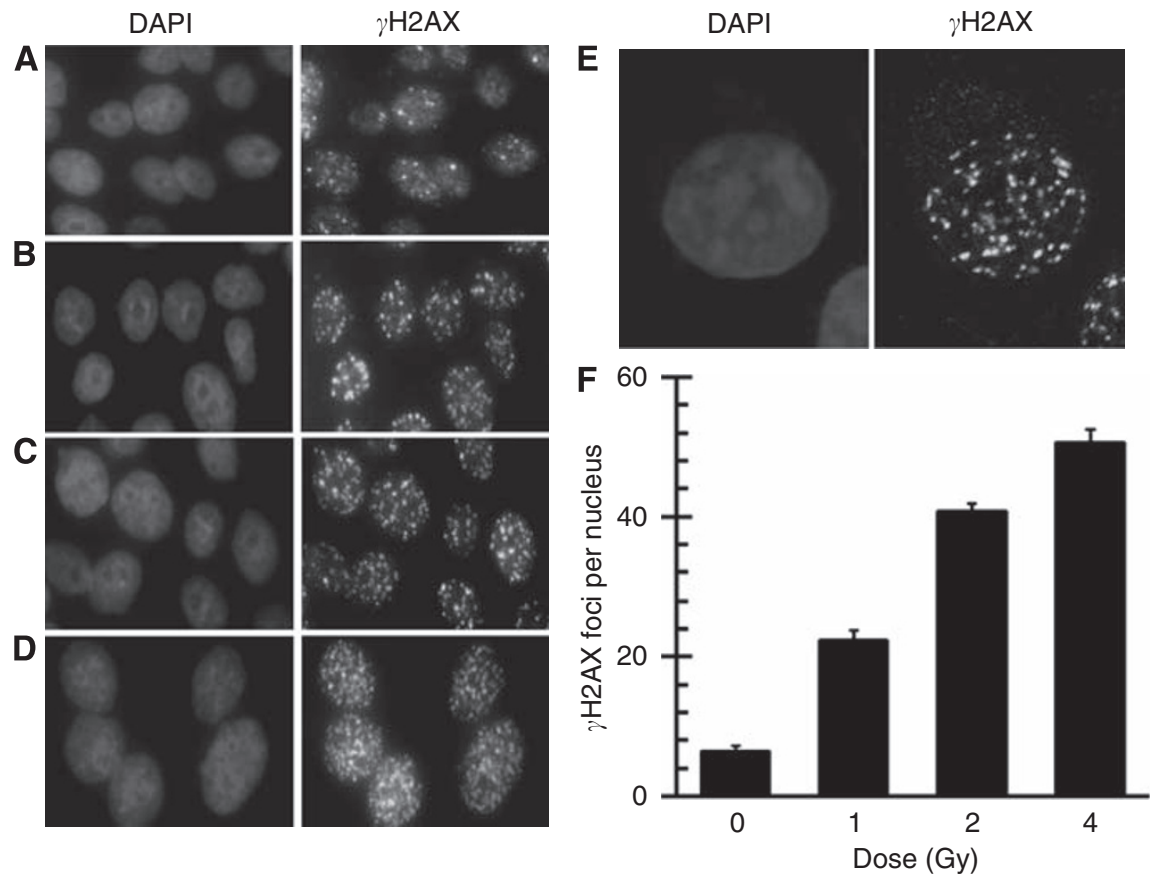

Figure I Dose response of $\gamma \mathrm{H} 2 \mathrm{AX}$ focus formation in lymphoblast cell lines (LCLs). Immunocytochemistry (ICC) was used to capture representative $\gamma \mathrm{H} 2 \mathrm{AX}$ focus images from asynchronous log-phase non-radiosensitive (RS) control cells (control-5) before (A) and I h after I Gy (B), 2 Gy (C) and 4 Gy (D) of ionising radiation (IR). (E) A more detailed view of $\gamma \mathrm{H} 2 \mathrm{AX}$ focus distribution, apparently not limited to either euchromatin or heterochromatin in a cell exposed to 2 Gy of IR. Slides were counterstained with DAPI to visualise nuclei (left panels). $\gamma \mathrm{H} 2 \mathrm{AX}$ foci were quantified as foci per nucleus for each dose (F). Error bars are the standard error of the mean (s.e.m.) of $\gamma \mathrm{H} 2 \mathrm{AX}$ foci number per nucleus from three separate experiments, wherein at least I00 nuclei cells were scored per dose.

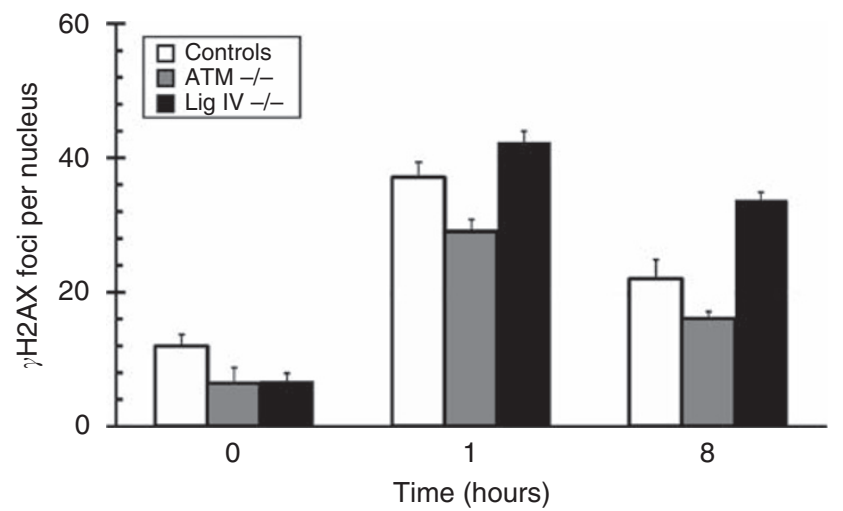

Figure 2 Time-course kinetics of DNA repair-deficient LCLs. $\gamma \mathrm{H} 2 \mathrm{AX}$ foci per nucleus are shown for controls ( $n=11$; open bars), homozygous ATM mutant (three experimental replicates; grey bars) and ligase IV knockout (three experimental replicates; black bars) human cell lines. $\gamma \mathrm{H} 2 \mathrm{AX}$ foci number was counted in cells before $(0 \mathrm{~h})$ and $\mathrm{I}$ and $8 \mathrm{~h}$ after exposure to $2 \mathrm{~Gy}$ of IR. Error bars represent s.e.m. of $\gamma \mathrm{H} 2 \mathrm{AX}$ foci number per nucleus.

similar kinetics to control cells, but have an elevated number of residual, perhaps complex, DNA DSBs (Kuhne et al, 2004).

We aimed to determine whether there was a link between clinical RS and the response to radiation as measured by $\gamma \mathrm{H} 2 \mathrm{AX}$ ICC. Therefore, we analysed a relatively large cohort of 18 LCLs derived from RT patients who showed severe (RTOG $\geqslant 3$ ) adverse normal tissue RT reactions and 11 non-RS control cancer patients. Background foci varied between the cell lines, with a range of 4-23 and a median of about 12 foci per nucleus. Treatment with $2 \mathrm{~Gy}$ of IR yielded around 35 foci per nucleus on an average within the first hour (Figure 3 ). There was a slow decline in visible $\gamma \mathrm{H} 2 \mathrm{AX}$ foci, which resulted in about 20-25 foci per nucleus on an average, after

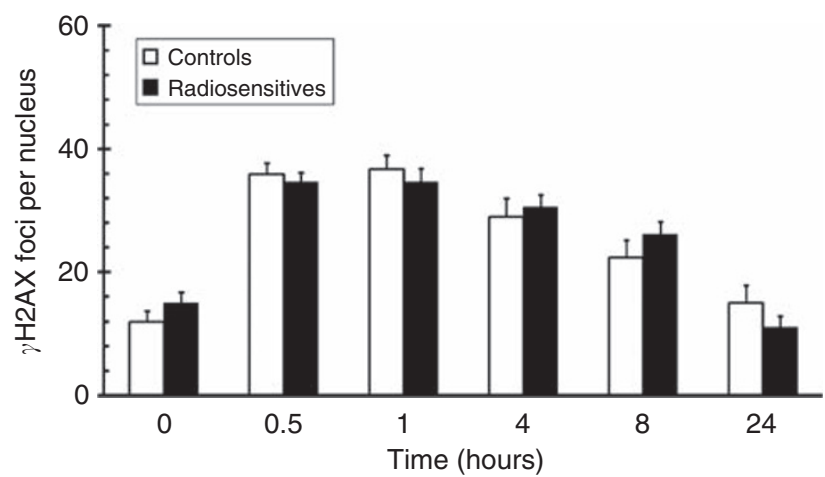

Figure 3 Time-course kinetics of IR-induced $\gamma \mathrm{H} 2 \mathrm{AX}$ foci in LCLs derived from clinically RS individuals $(n=18)$ vs control LCLs $(n=11)$ $\gamma \mathrm{H} 2 \mathrm{AX}$ focus number was measured in control (open bars) and RS (filled bars) cell lines before $(0 \mathrm{~h})$ and at various times after $2 \mathrm{~Gy}$ of IR. Error bars represent s.e.m. of foci number per nucleus based on 4-5 fields of approximately $20-25$ cells per field. Data have been graphed from 0 to $8 \mathrm{~h}$ for all RS and CL cell lines (controls: $n=11$; RS: $n=18$ ), and at $24 \mathrm{~h}$ for a random subset of cell lines (controls: $n=5$ [CLI, CL3, CL4, CL9, CLI I]; RS: $n=13$ [AI, A2, A3, A4, A6, A7, L3, L5, L6, L7, L9, LI I]) (Table I).

$8 \mathrm{~h}$ post-IR (Figure 3 ). The average rate of $\gamma \mathrm{H} 2 \mathrm{AX}$ depletion from the first hour to $8 \mathrm{~h}$ following IR was 2 foci and 1.2 foci per hour for controls and RSs, respectively. A subset of these samples $(n=\mathrm{CL}-5 ; \mathrm{RS}=13)$ were analysed at $24 \mathrm{~h}$ post-IR and showed a further decrease in foci number, approximately to background levels (Figure 3). Statistical analysis revealed no significant difference between control and RS samples, on average.

Clinical RS can be classified into two main types: acute, wherein the adverse effects are apparent during or soon after treatment, and late, wherein the adverse reactions, such as fibrosis, present an 
adverse phenotype 6 months or longer following radiation treatment. Therefore, we sub-divided our cell lines into these two categories for further analysis (Figure 4). One cell line, RS1, stood out with a relatively slow rate of $\gamma \mathrm{H} 2 \mathrm{AX}$ foci depletion after 4,8 and $24 \mathrm{~h}$. This cell line was subjected to additional testing for $\gamma \mathrm{H} 2 \mathrm{AX}$ foci induction. We confirmed the slow $\gamma \mathrm{H} 2 \mathrm{AX}$ foci depletion for this cell line in two independent experiments (Figure 5A). The $\gamma \mathrm{H} 2 \mathrm{AX}$ foci levels of the RS1 cell line were also

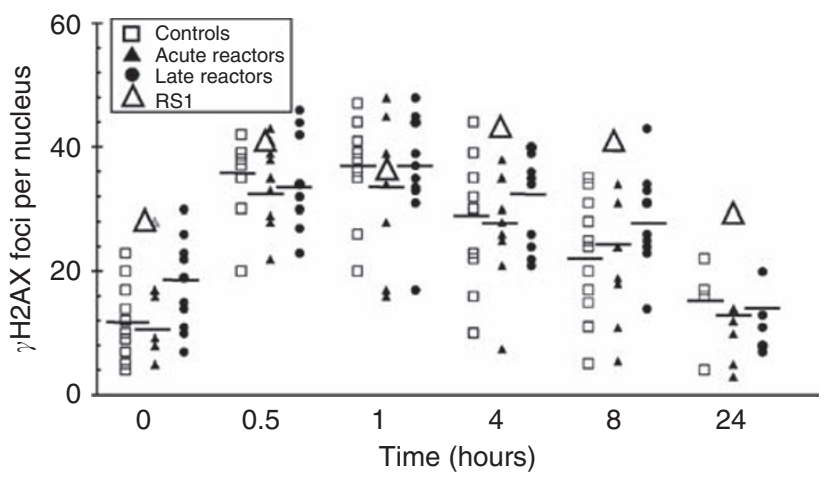

Figure 4 Time-course kinetics of $\gamma H 2 A X$ focus induction and repair for each $L C L$ following IR. $\gamma \mathrm{H} 2 \mathrm{AX}$ focus numbers per nucleus before $(\mathrm{O} h)$ and at various times after $2 \mathrm{~Gy}$ are plotted for each control cell line (open squares), acute (filled triangles) and late (filled circles) RS patients. RSI is designated as an open triangle. checked at a longer time point $(24 \mathrm{~h})$ and found to have 29 foci, much higher than any of the controls $(n=5)$, which had an average of 15 foci after $24 \mathrm{~h}$ of recovery (Figures 4 and 5 ). We also observed that RS1 had higher basal levels of $\gamma \mathrm{H} 2 \mathrm{AX}$ foci (Figure 5A and $\mathrm{B})$, perhaps reflecting genomic instability in this transformed cell line.

We also wanted to confirm, in an independent DNA DSB repair assay, the impaired DNA DSB repair phenotype in RS1 cells, and examined it using PFGE, which directly detects the repair of highmolecular-weight DNA fragments by quantifying DNA release from the wells of an agarose gel. Consistent with the $\gamma \mathrm{H} 2 \mathrm{AX}$ foci results, we also found in the RS1 LCLs that there was more residual DNA fragmentation after various times of recovery, relative to controls, confirming impaired DNA DSB repair in the cell line (Figure 5C).

\section{DISCUSSION}

The RS patients' whose cells were studied here were from phenotypically normal individuals with unexpected severe RT reactions in their normal tissues; no cases had the stigmata of the known RS syndromes, involving genes such as ATM, NBS and $B R C A$. A subset of the RS cases and controls had previously been screened for mutations in the BRCA1 and BRCA2 cancer predisposition/radiation response genes, with no definite mutations being found (Leong et al, 2000).

Our results are consistent with others (Kuhne et al, 2004) in that we found a clear difference in IR-induced $\gamma \mathrm{H} 2 \mathrm{AX}$ foci depletion in

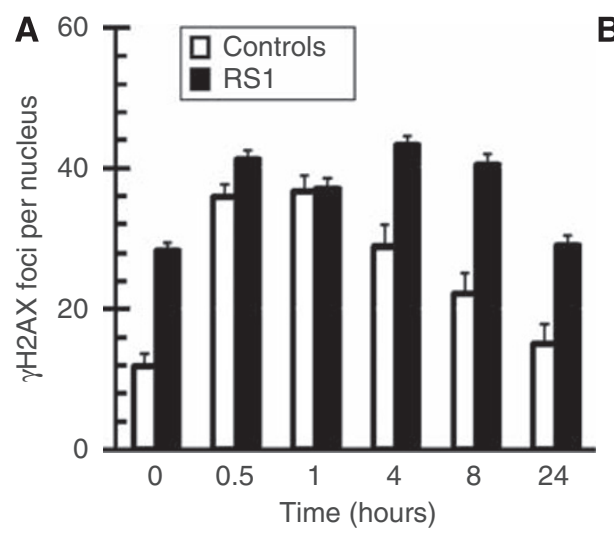

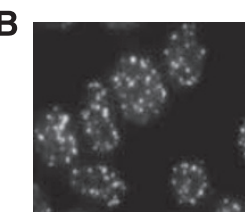
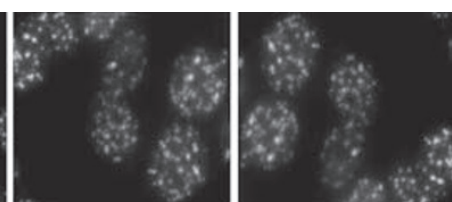

0

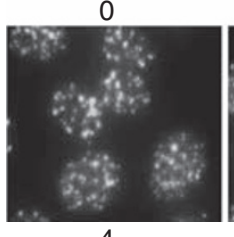

0.5
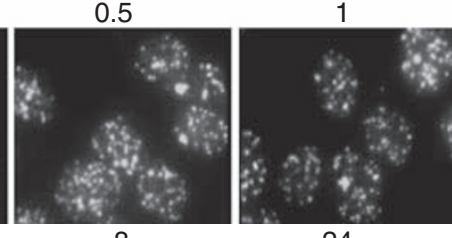

24

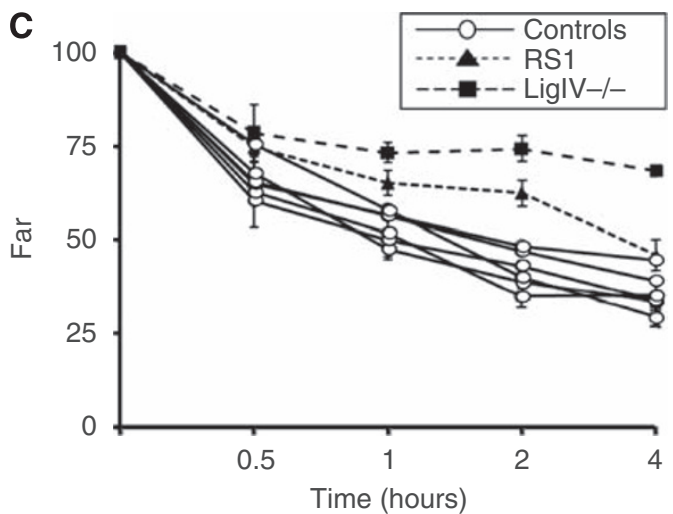

Figure 5 Dynamics of DNA repair in LCLs from an RS individual (RSI) following IR. (A) $\gamma H 2 A X$ focus numbers for unirradiated ( $0 h$ ) cells and irradiated cells at various time intervals after 2 Gy of IR are shown for control cell lines (open bars) and the RSI cell line from two separate experiments (filled bars). Error bars represent s.e.m. of foci number per nucleus determined from I I control cell lines and two replicates of RSI. (B) Representative $\gamma H 2 A X$ ICC focus images are shown for asynchronous log-phase RSI cells before and at the indicated times (hours) after 2 Gy of IR. (C) Pulsed-field gel electrophoresis (PFGE) was carried out on RSI (filled triangles), and a ligase IV-deficient cell line (filled squares) after various time points (in hours) along with six controls (open circles; CLI, CL2, CL5, CL9, CLI0, CLII) following 40 Gy of radiation. Error bars represent the differences in mean from two separate experiments, each determined from two replicates run on separate gels. 
a human cell line for which an important gene in DNA repair, DNA ligase IV, has been knocked out, showing the applicability of these molecular methods to RS cell lines. However, we observed no detectable difference between the control group and the RS group as a whole by following $\gamma \mathrm{H} 2 \mathrm{AX}$ foci kinetics after IR. Nevertheless, we did find one cell line from the group of RS patient-derived cell lines that showed similar $\gamma \mathrm{H} 2 \mathrm{AX}$ kinetics to the ligase IV knockout cell line, which was confirmed by using a direct DNA damage and repair assay. We believe that the $\gamma \mathrm{H} 2 \mathrm{AX}$ assay has the potential to perform better than many other cellular RS predictive assays because it detects a very early event, but is still measurable for a reasonable period of time following DNA damage. Moreover, DSBs can be directly correlated with foci, and these can be directly visualised in situ. Besides, we noted less variability in the RS1 cell line using the $\gamma \mathrm{H} 2 \mathrm{AX}$ assay compared with the PFGE DNA damage and repair assay. Most investigations of cellular response to radiation normally use doses that are well above the threshold of the mean lethal total body dose of $4 \mathrm{~Gy}$ in humans. The $\gamma \mathrm{H} 2 \mathrm{AX}$ assay circumvents confounding problems that may be associated with dose.

We contend that the slow rate of depletion of visible $\gamma \mathrm{H} 2 \mathrm{AX}$ foci in RS1 relative to controls may be because of the factors that led to the patients' acute clinical RS. The RS1 patient showed a particularly striking acute reaction with strong erythema after only a cumulative $10 \mathrm{~Gy}$ dose of IR. We presume that both the high basal foci levels and the DNA repair defect in RS1 are because of the same defect.

We also observed a large inter-cell line range of $\gamma \mathrm{H} 2 \mathrm{AX}$ foci at the basal level, as well as at different times following IR. This is consistent with previous reports using the $\gamma \mathrm{H} 2 \mathrm{AX}$ assay (Ismail et al, 2007), as well as with other RS assays. Therefore, the $\gamma \mathrm{H} 2 \mathrm{AX}$ assay used here may not be able to pick up some cell lines with different types or moderate DNA repair defects because of a relatively high variance; however, it still may be better than other common RS assays. It was clearly competent for detecting basal levels predictive of faulty DNA repair. We determined that the loss of $\gamma \mathrm{H} 2 \mathrm{AX}$ foci occurs with an half-life of approximately $6 \mathrm{~h}$ in control LCLs, but foci levels at this time for the RS1 cell line were still as high as the control levels at $0.5 \mathrm{~h}$ and $1 \mathrm{~h}$ following IR, and had a half life for foci loss that was much slower than that of controls over the first $8 \mathrm{~h}$.

A number of authors have shown using different assays of radiation response that Epstein - Barr virus (EBV) transformation may affect RS. However, alterations to RS have not tended to be systematic, nor to correlate with EBV load. We previously noted that (Lovelock et al, 2007):

'EBV-mediated immortalisation of lymphocytes results in alterations to levels of expression of a number of cell genes, including several transcription factors. Epstein-Barr Virus Nuclear Antigen-3 (EBNA-3) also disrupts the G2/M cell cycle checkpoint. As part of the immortalisation process, the normal cellular functions of lymphocytes are likely to be disrupted.....'.

In an attempt to control one variable in the immortalisation process, we confirmed by western blot that all LCLs used were transformed by the same EBNA2A EBV strain (Lovelock et al, 2007). For the clonogenic survival end point, LCL survival may cluster more than expected compared with non-transformed but cycling B-cells, which can show a wider spread of response (Maneerat $e t a l$, in preparation). By using the $\gamma \mathrm{H} 2 \mathrm{AX}$ assay as we have shown here, it is unknown whether clustering of data (i.e., just one clear outlier) may have been less if non-transformed cells had been used for the screen. However, the fact that ligase IV control LCLs were a clear outlier suggests that the assay as performed can pick up true RS independent of EBV transformation. Ideally, to resolve these issues, one would like to screen both immortalised and mortal cells from RS patients using assays that characterise a number of radiation-response end points. We did not observe unusually high basal levels of DNA damage in the RS1 cell line using the PFGE DNA damage and repair assay as we did in the $\gamma \mathrm{H} 2 \mathrm{AX}$ assay. This may be because the majority of variations in basal level breaks observed are due to the shearing caused during DNA processing, and the true initial DNA DSB levels are probably too low to be detected using the PFGE assay that uses such high IR doses. However, RS1 cells had an obvious lag in repair in the PFGE DNA damage and repair assay, which, even after $4 \mathrm{~h}$, was still relatively high compared with the average of the controls.

The defect in DNA repair in RS1 may be further explored by immunofluorescence co-localisation of other repair factors known to form foci at sites of DNA damage. In addition, expression analysis and the use of DNA repair protein functional studies will be pursued.

In conclusion, a fraction of patients who are predisposed to adverse reactions could be detected using ICC assays that detect $\gamma \mathrm{H} 2 \mathrm{AX}$ foci. This application, in combination with other predictive assessments, may eventually facilitate the tailoring of RT regimes to individuals, which could result in lesser side effects of RT and better tumour control.

\section{ACKNOWLEDGEMENTS}

This research was supported by the Australian National Health and Medical Research Council Project Grants no. 145780 and no. 288713 to CNS and MJM, and a National Breast Cancer Foundation grant (Australia) to CNS and MJM. RSV was supported by a Melbourne University International Research Scholarship. We thank Hugette Janetski and Masayo Tada for secretarial assistance.

Supplementary Information accompanies the paper on British Journal of Cancer website (http://www.nature.com/bjc)

\section{REFERENCES}

Alsner J, Andreassen CN, Overgaard J (2008) Genetic markers for prediction of normal tissue toxicity after radiotherapy. Semin Radiat Oncol 18: $126-135$

Banath JP, Macphail SH, Olive PL (2004) Radiation sensitivity, H2AX phosphorylation, and kinetics of repair of DNA strand breaks in irradiated cervical cancer cell lines. Cancer Res 64: 7144-7149

Bassing CH, Alt FW (2004) H2AX may function as an anchor to hold broken chromosomal DNA ends in close proximity. Cell Cycle 3: 149-153

Bassing CH, Chua KF, Sekiguchi J, Suh H, Whitlow SR, Fleming JC, Monroe BC, Ciccone DN, Yan C, Vlasakova K, Livingston DM, Ferguson DO, Scully R, Alt FW (2002) Increased ionizing radiation sensitivity and genomic instability in the absence of histone H2AX. Proc Natl Acad Sci USA 99: $8173-8178$

Bouquet F, Muller C, Salles B (2006) The loss of gammaH2AX signal is a marker of DNA double strand breaks repair only at low levels of DNA damage. Cell Cycle 5: 1116-1122

Brammer I, Zoller M, Dikomey E (2001) Relationship between cellular radiosensitivity and DNA damage measured by comet assay in human normal, NBS and AT fibroblasts. Int J Radiat Biol 77: $929-938$

Brock WA, Tucker SL, Geara FB, Turesson I, Wike J, Nyman J, Peters LJ (1995) Fibroblast radiosensitivity versus acute and late normal skin responses in patients treated for breast cancer. Int J Radiat Oncol Biol Phys 32: $1371-1379$

Burma S, Chen DJ (2004) Role of DNA-PK in the cellular response to DNA double-strand breaks. DNA Repair (Amst) 3: 909-918 
Celeste A, Fernandez-Capetillo O, Kruhlak MJ, Pilch DR, Staudt DW, Lee A, Bonner RF, Bonner WM, Nussenzweig A (2003) Histone H2AX phosphorylation is dispensable for the initial recognition of DNA breaks. Nat Cell Biol 5: 675-679

Chowdhury D, Keogh MC, Ishii H, Peterson CL, Buratowski S, Lieberman J (2005) gamma-H2AX dephosphorylation by protein phosphatase 2A facilitates DNA double-strand break repair. Mol Cell 20: $801-809$

Distel L, Neubauer S, Varon R, Holter W, Grabenbauer G (2003) Fatal toxicity following radio- and chemotherapy of medulloblastoma in a child with unrecognized Nijmegen breakage syndrome. Med Pediatr Oncol 41: 44-48

Distel LV, Neubauer S, Keller U, Sprung CN, Sauer R, Grabenbauer GG (2006) Individual differences in chromosomal aberrations after in vitro irradiation of cells from healthy individuals, cancer and cancer susceptibility syndrome patients. Radiother Oncol 81: 257-263

Gurska S, Farkasova T, Gabelova A (2007) Radiosensitivity of cervical cancer cell lines: the impact of polymorphisms in DNA repair genes. Neoplasma 54: 195-201

Ismail IH, Wadhra TI, Hammarsten O (2007) An optimized method for detecting gamma-H2AX in blood cells reveals a significant interindividual variation in the gamma-H2AX response among humans. Nucleic Acids Res 35: e36

Ismail SM, Puppi M, Prithivirajsingh S, Munshi A, Raju U, Meyn RE, Buchholz TA, Story MD, Brock WA, Milas L, Thames HD, Stevens CW (2004) Predicting radiosensitivity using DNA end-binding complex analysis. Clin Cancer Res 10: 1226-1234

Keogh MC, Kim JA, Downey M, Fillingham J, Chowdhury D, Harrison JC, Onishi M, Datta N, Galicia S, Emili A, Lieberman J, Shen X, Buratowski S, Haber JE, Durocher D, Greenblatt JF, Krogan NJ (2006) A phosphatase complex that dephosphorylates gammaH2AX regulates DNA damage checkpoint recovery. Nature 439: 497-501

Klokov D, MacPhail SM, Banath JP, Byrne JP, Olive PL (2006) Phosphorylated histone $\mathrm{H} 2 \mathrm{AX}$ in relation to cell survival in tumor cells and xenografts exposed to single and fractionated doses of X-rays. Radiother Oncol 80: 223-229

Kuhne M, Riballo E, Rief N, Rothkamm K, Jeggo PA, Lobrich M (2004) A double-strand break repair defect in ATM-deficient cells contributes to radiosensitivity. Cancer Res 64: 500-508

Kusch T, Florens L, Macdonald WH, Swanson SK, Glaser RL, Yates III JR, Abmayr SM, Washburn MP, Workman JL (2004) Acetylation by Tip60 is required for selective histone variant exchange at DNA lesions. Science 306: $2084-2087$

Leong T, Whitty J, Keilar M, Mifsud S, Ramsay J, Birrell G, Venter D, Southey M, McKay M (2000) Mutation analysis of BRCA1 and BRCA2 cancer predisposition genes in radiation hypersensitive cancer patients. Int J Radiat Oncol Biol Phys 48: 959-965

Lovelock PK, Wong EM, Sprung CN, Marsh A, Hobson K, French JD, Southey M, Sculley T, Pandeya N, Brown MA, Chenevix-Trench G, Spurdle AB, kConFab Investigators, McKay MJ (2007) Prediction of BRCA1 and BRCA2 mutation status using post-irradiation assays of lymphoblastoid cell lines is compromised by inter-cell-line phenotypic variability. Breast Cancer Res Treat 104(3): 257-266

MacPhail SH, Banath JP, Yu TY, Chu EH, Lambur H, Olive PL (2003) Expression of phosphorylated histone $\mathrm{H} 2 \mathrm{AX}$ in cultured cell lines following exposure to X-rays. Int J Radiat Biol 79: 351-358

Mahrhofer H, Burger S, Oppitz U, Flentje M, Djuzenova CS (2006) Radiation induced DNA damage and damage repair in human tumor and fibroblast cell lines assessed by histone $\mathrm{H} 2 \mathrm{AX}$ phosphorylation. Int $J$ Radiat Oncol Biol Phys 64: 573-580

McGowan CH, Russell P (2004) The DNA damage response: sensing and signaling. Curr Opin Cell Biol 16: 629-633

McIlrath J, Bouffler SD, Samper E, Cuthbert A, Wojcik A, Szumiel I, Bryant PE, Riches AC, Thompson A, Blasco MA, Newbold RF, Slijepcevic P (2001) Telomere length abnormalities in mammalian radiosensitive cells. Cancer Res 61: $912-915$

McKay MJ, Kefford RF (1995) The spectrum of in vitro radiosensitivity in four human melanoma cell lines is not accounted for by differential induction or rejoining of DNA double strand breaks. Int J Radiat Oncol Biol Phys 31: 345-352

Morgan G, Ward R, Barton M (2004) The contribution of cytotoxic chemotherapy to 5-year survival in adult malignancies. Clin Oncol ( $R$ Coll Radiol) 16: 549-560

Nachtrab U, Oppitz U, Flentje M, Stopper H (1998) Radiation-induced micronucleus formation in human skin fibroblasts of patients showing severe and normal tissue damage after radiotherapy. Int J Radiat Biol 73: $279-287$

Neitzel H (1986) A routine method for the establishment of permanent growing lymphoblastoid cell lines. Hum Genet 73: 320-326

Nelms BE, Maser RS, MacKay JF, Lagally MG, Petrini JH (1998) In situ visualization of DNA double-strand break repair in human fibroblasts. Science 280: $590-592$

Neubauer S, Arutyunyan R, Stumm M, Dork T, Bendix R, Bremer M, Varon R, Sauer R, Gebhart E (2002) Radiosensitivity of ataxia telangiectasia and Nijmegen breakage syndrome homozygotes and heterozygotes as determined by three-color FISH chromosome painting. Radiat Res 157: $312-321$

Neubauer S, Dunst J, Gebhart E (1997) The impact of complex chromosomal rearrangements on the detection of radiosensitivity in cancer patients. Radiother Oncol 43: 189-195

Olive PL, Banath JP (2004) Phosphorylation of histone H2AX as a measure of radiosensitivity. Int J Radiat Oncol Biol Phys 58: 331-335

Olive PL, Banath JP, Keyes M (2008) Residual gammaH2AX after irradiation of human lymphocytes and monocytes in vitro and its relation to late effects after prostate brachytherapy. Radiother Oncol 86: $336-346$

Paull TT, Rogakou EP, Yamazaki V, Kirchgessner CU, Gellert M, Bonner WM (2000) A critical role for histone H2AX in recruitment of repair factors to nuclear foci after DNA damage. Curr Biol 10: $886-895$

Petersen S, Casellas R, Reina-San-Martin B, Chen HT, Difilippantonio MJ, Wilson PC, Hanitsch L, Celeste A, Muramatsu M, Pilch DR, Redon C, Ried T, Bonner WM, Honjo T, Nussenzweig MC, Nussenzweig A (2001) AID is required to initiate Nbs1/gamma-H2AX focus formation and mutations at sites of class switching. Nature 414: 660-665

Qvarnström OF, Simonsson M, Johansson KA, Nyman J, Turesson I (2004) DNA double strand break quantification in skin biopsies. Radiother Oncol 72: $311-317$

Rieger KE, Hong WJ, Tusher VG, Tang J, Tibshirani R, Chu G (2004) Toxicity from radiation therapy associated with abnormal transcriptional responses to DNA damage. Proc Natl Acad Sci USA 101: 6635-6640

Rogakou EP, Boon C, Redon C, Bonner WM (1999) Megabase chromatin domains involved in DNA double-strand breaks in vivo. J Cell Biol 146: 905-916

Rogakou EP, Pilch DR, Orr AH, Ivanova VS, Bonner WM (1998) DNA double-stranded breaks induce histone $\mathrm{H} 2 \mathrm{AX}$ phosphorylation on serine 139. J Biol Chem 273: $5858-5868$

Sedelnikova OA, Rogakou EP, Panyutin IG, Bonner WM (2002) Quantitative detection of (125)IdU-induced DNA double-strand breaks with gamma-H2AX antibody. Radiat Res 158: 486-492

Severin DM, Leong T, Cassidy B, Elsaleh H, Peters L, Venter D, Southey M, McKay M (2001) Novel DNA sequence variants in the hHR21 DNA repair gene in radiosensitive cancer patients. Int J Radiat Oncol Biol Phys 50: $1323-1331$

Shiloh Y (2001) ATM and ATR: networking cellular responses to DNA damage. Curr Opin Genet Dev 11: 71-77

Shiloh Y (2003) ATM and related protein kinases: safeguarding genome integrity. Nat Rev Cancer 3: $155-168$

Sprung CN, Chao M, Leong T, McKay MJ (2005) Chromosomal radiosensitivity in two cell lineages derived from clinically radiosensitive cancer patients. Clin Cancer Res 11: 6352-6358

Sprung CN, Davey DS, Withana NP, Distel LV, McKay MJ (2008) Telomere length in lymphoblast cell lines derived from clinically radiosensitive cancer patients. Cancer Biol Ther 7: 1-7

Sprung CN, Mathews LJ, McKay MJ (2002) DNA repair deficiencies: connecting carcinogenesis and sensitivity to ionising radiation. Today's Life Science 14: $40-44$

Spycher C, Miller ES, Townsend K, Pavic L, Morrice NA, Janscak P, Stewart GS, Stucki M (2008) Constitutive phosphorylation of MDC1 physically links the MRE11-RAD50-NBS1 complex to damaged chromatin. J Cell Biol 181: 227-240

Stucki M, Jackson SP (2006) gammaH2AX and MDC1: anchoring the DNAdamage- response machinery to broken chromosomes. DNA Repair (Amst) 5: 534-543

Svensson JP, Stalpers LJ, Esveldt-van Lange RE, Franken NA, Haveman J, Klein B, Turesson I, Vrieling H, Giphart-Gassler M (2006) Analysis of gene expression using gene sets discriminates cancer patients with and without late radiation toxicity. PLoS Med 3: e422

Svetlova M, Solovjeva L, Nishi K, Nazarov I, Siino J, Tomilin N (2007) Elimination of radiation-induced gamma- $\mathrm{H} 2 \mathrm{AX}$ foci in mammalian 
nucleus can occur by histone exchange. Biochem Biophys Res Commun 358: $650-654$

Taneja N, Davis M, Choy JS, Beckett MA, Singh R, Kron SJ, Weichselbaum RR (2004) Histone H2AX phosphorylation as a predictor of radiosensitivity and target for radiotherapy. J Biol Chem 279: 2273-2280

Vilenchik MM, Knudson AG (2003) Endogenous DNA double-strand breaks: production, fidelity of repair, and induction of cancer. Proc Natl Acad Sci USA 100: 12871-12876

West CM, Davidson SE, Elyan SA, Swindell R, Roberts SA, Orton CJ, Coyle CA, Valentine H, Wilks DP, Hunter RD, Hendry JH (1998) The intrinsic radiosensitivity of normal and tumour cells. Int J Radiat Biol 73: 409-413
Wilding CS, Curwen GB, Tawn EJ, Sheng X, Winther JF, Chakraborty R, Boice Jr JD (2007) Influence of polymorphisms at loci encoding DNA repair proteins on cancer susceptibility and G2 chromosomal radiosensitivity. Environ Mol Mutagen 48: 48-57

Wurm R, Burnet NG, Duggal N, Yarnold JR, Peacock JH (1994) Cellular radiosensitivity and DNA damage in primary human fibroblasts. Int $J$ Radiat Oncol Biol Phys 30: 625-633

Zhou PK, Sproston AR, Marples B, West CM, Margison GP, Hendry JH (1998) The radiosensitivity of human fibroblast cell lines correlates with residual levels of DNA double-strand breaks. Radiother Oncol 47: $271-276$ 